\title{
Spectrum of Gestational Trophoblastic Disease Secondary to Dilation and Evacuation - Our Experience at a Tertiary Care Centre in Mullana, Ambala
}

\author{
Akshat Kuchhal ${ }^{1}$, Harneet Narula², Amit Jain ${ }^{3}$, Shivangi Jain ${ }^{4}$ \\ 1,2,3 Department of Radio Diagnosis, Maharishi Markandeshwar Institute of Medical Sciences and Research (Deemed to \\ Be University), Mullana, Ambala, Haryana, India. ${ }^{4}$ Department of Obstetrics and Gynaecology, Maharishi Markandeshwar \\ Institute of Medical Sciences and Research (Deemed to Be University), Mullana, Ambala, Haryana, India.
}

\section{ABSTRACT}

\section{BACKGROUND}

Gestational trophoblastic diseases have varying clinical presentations with certain diagnostic signs and symptoms. A strong correlation between gestational trophoblastic diseases (GTD) and a previous history of dilation \& evacuation (D \& E) has been documented in the limited available literature. We wanted to study the spectrum of gestational trophoblastic disease secondary to dilation \& evacuation.

\section{METHODS}

A two-year study including all the females who were admitted to MMIMSR Hospital in view of suspicion of gestational trophoblastic disease was conducted with all having a common history of dilatation and evacuation in the recent past.

\section{RESULTS}

Through the analysis we saw the spectrum of GTD including partial mole, complete mole, invasive mole and choriocarcinoma, as well as its complications in the form of arterio-venous malformation (AVM).

\section{CONCLUSIONS}

The two-year experience suggests that dilatation and curettage may predispose a female of reproductive age group to develop gestational trophoblastic disease in the future. Hence, a high index of suspicion is necessary for timely diagnosis and intervention. The study further helped us understand the wide spectrum of the disease and its associated complications.

\section{KEY WORDS}

Abortion, AVM, Dilatation and Evacuation, GTD, GTN
Corresponding Author:

Dr. Shivangi Jain,

Room 104, I-Block,

Maharishi Markandeshwar

Institute of Medical Sciences and

Research (Deemed to Be University),

Mullana, Ambala - 133207,

Haryana, India.

E-mail: shivangijain2393@gmail.com

DOI: $10.14260 / j e m d s / 2021 / 237$

How to Cite This Article:

Kuchhal A, Narula H, Jain A, et al. Spectrum of gestational trophoblastic disease secondary to dilation \& evacuation - our experience at a tertiary care centre in Mullana, Ambala. J Evolution Med Dent Sci 2021;10(16):1106-1113, 10.14260/jemds/2021/237

Submission 03-12-2020,

Peer Review 18-02-2021,

Acceptance 25-02-2021, Published 19-04-2021.

Copyright (C) 2021 Akshat Kuchhal et al. This is an open access article distributed under Creative Commons Attribution License [Attribution 4.0 International (CC BY 4.0)] 


\section{BACKGROUND}

Dilatation and evacuation are widely used methods for uterine evacuation following early pregnancy complications including abortions or GTD's. D \& E is the method of choice for management of complete molar pregnancy as well as partial molar pregnancy except when the size of the fetal parts defers the use of curettage when medical management can be used.

Gestational trophoblastic diseases include a wide spectrum of presentations including partial as well as complete molar pregnancy, invasive mole, choriocarcinoma, placental site trophoblastic tumour and epithelioid trophoblastic tumour. The latter four entities are clubbed together and referred to as gestational trophoblastic neoplasia (GTN). Recently, the spectrum of GTD has been expanded to also include a new entity namely atypical placental site nodule (APSN) as few of these lesions may coexist with or develop into placental site trophoblastic tumour (PSTT) / epithelioid trophoblastic tumour (ETT). ${ }^{1} \mathrm{~A}$ high incidence of correlation with previous history of $\mathrm{D} \& \mathrm{E}$ has often been described in the limited available literature.

We wanted to study the spectrum of gestational trophoblastic disease secondary to dilation \& evacuation.

\section{METHODS}

This was a case series conducted over a period of two-years from September 2018 to September 2020.

\section{Collection of Data}

All patients referred to the Department of Radio Diagnosis with clinically / ultrasound diagnosed GTD or its spectrum were part of the study.

\section{Inclusion Criteria}

- All patients clinically suspected to have GTD or its spectrum disorder.

- All patients with diagnosed GTD or its spectrum on ultrasound / computed tomography (CT) /magnetic resonance imaging (MRI).

A complete detailed clinical history of the patient was taken. Chief complaints and a thorough clinical examination including local and systemic examinations were performed. Relevant biochemical and blood investigations were sent for. Ultrasonography (USG) was done in all cases as the first line imaging modality of choice. Further use of advanced imaging modalities including $\mathrm{CT} \pm$ contrast or MRI \pm contrast, depending on the provisional diagnosis, as per the need, patient's condition and feasibility at the moment, were performed.

After the scan, all the images were evaluated in axial, coronal and sagittal plane. Findings were recorded and correlated with clinical / biochemical / imaging / biopsy / surgical findings.

Appropriate management as per the protocol was recommended to the treating clinician as per the findings. A detailed follow-up was done for all the patients included in the study and shall be mentioned in the text.

\section{Case Details}

Patient 1

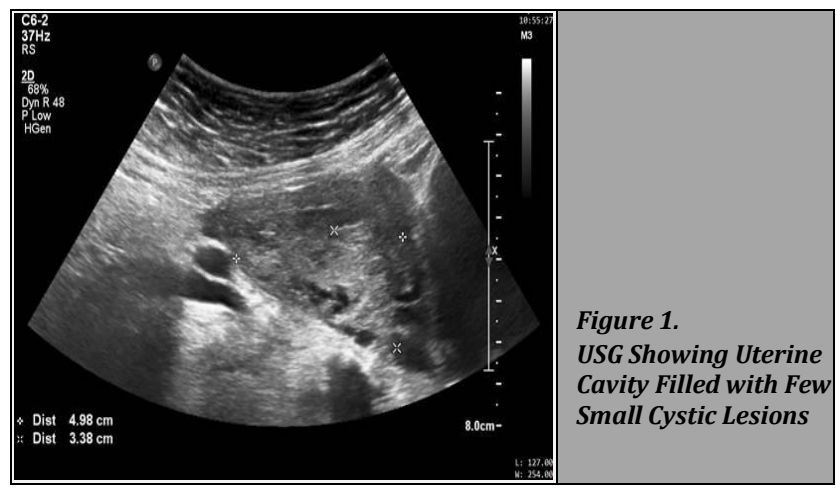

A 32-year-old-female presented with amenorrhoea of 2 months and bleeding per vaginal for last 5 days. She had a history of incomplete abortion 8 months back for which D \& E was performed. Her B-Hcg level was $3200 \mathrm{mIU} / \mathrm{ml}$ and USG showed few small cystic lesions occupying part of the uterine cavity with no appreciable fetal tissue, s / o complete molar pregnancy. She was taken up for D \& E and the curetting's were sent for histopathology which was suggestive of molar pregnancy. Sequential reduction in B-Hcg levels were observed on weekly follow ups.

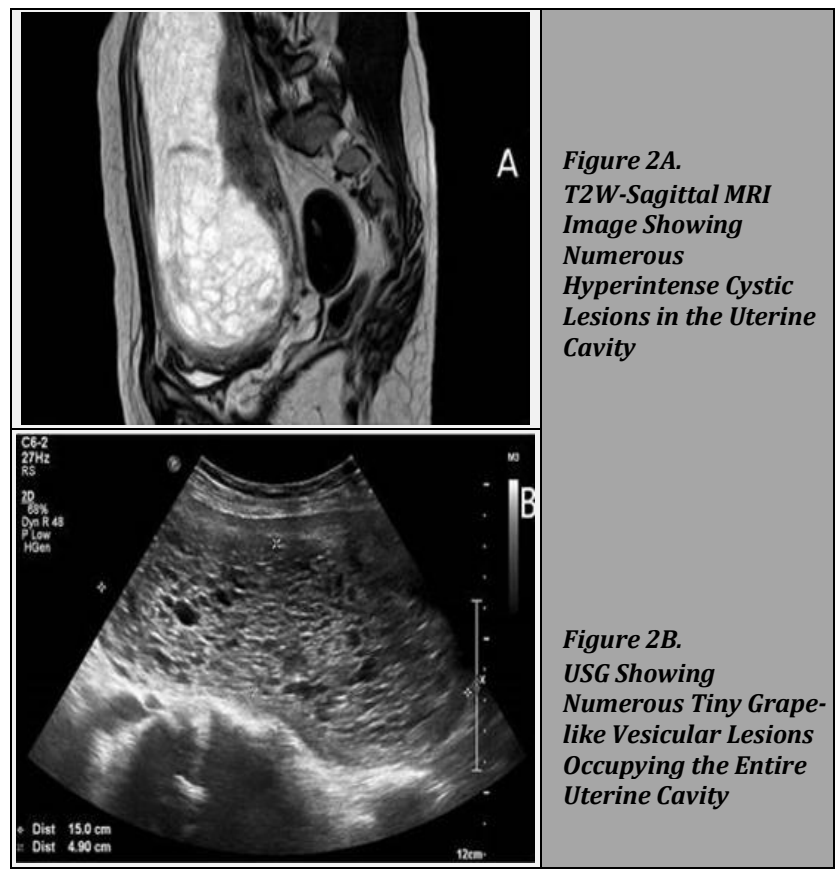

Patient 2

30-year-old-female P2L1A1 presented with amenorrhoea of 4 months and bleeding per vaginal for last 2 days. She gave a history of delivering an intrauterine fetal demise (IUFD) fetus at 9 months gestation wherein due to adherent retained products of conception (RPOC) she underwent D \& E. B-Hcg level was 21,000 mIU / ml. USG and MRI revealed cystic lesions occupying the entire uterine cavity with no signs of myometrial invasion. A diagnosis of complete molar 
pregnancy was made for which she underwent D\&E and was discharged in a satisfactory condition with sequential reduction in the levels of B-Hcg on weekly follow-up.

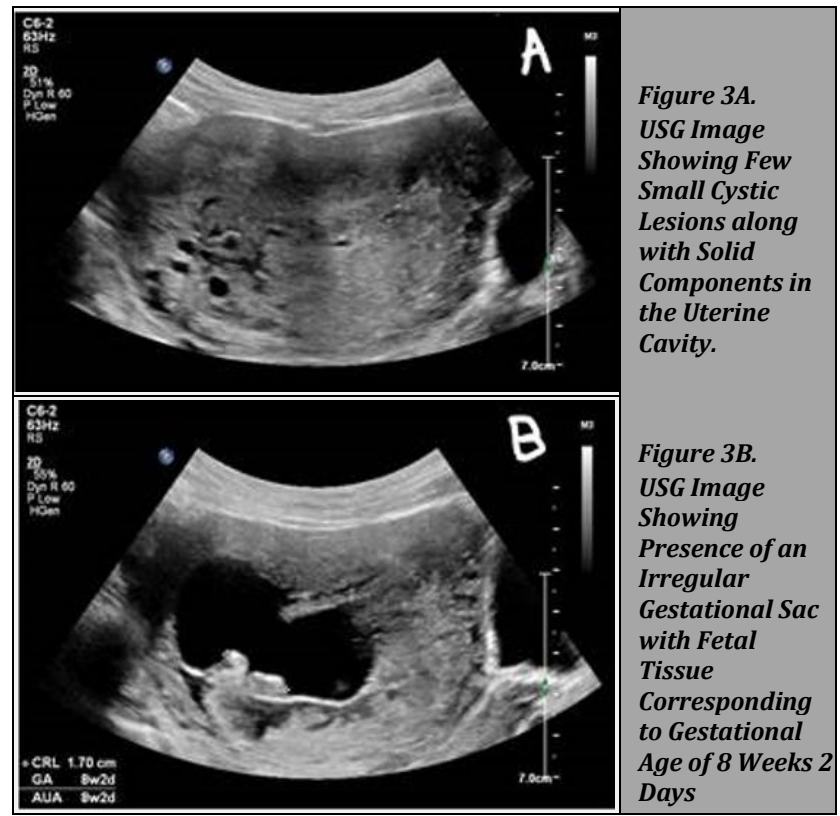

Patient 3

24-year-old-female G2P1L1 presented with amenorrhoea of 4 months, severe abdominal pain and recurrent episodes of vomiting for the last 2 days. She had a history of D \& E, I / v / o RPOC's following a normal vaginal delivery 3 years back. B-Hcg level was 43,200 mIU / ml. USG showed uterine cavity filled with multiple cystic as well as solid components with an irregular gestational sac with fetal tissue corresponding to gestational age of 8 weeks 2 days with absent cardiac activity. A diagnosis of partial molar pregnancy was made. She underwent $\mathrm{D} \& \mathrm{E}$ for the same and was discharged in a satisfactory condition with sequential reduction in the levels of B-HCG.

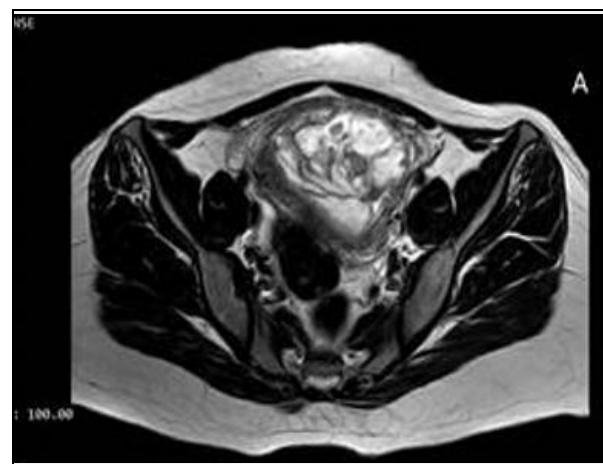

Figure 4A.

T2W-Axial MRI

Showing Cystic

as well as Solid

Components in

the Uterine

Cavity with

Myometrial

Thinning as Well as Invasion.

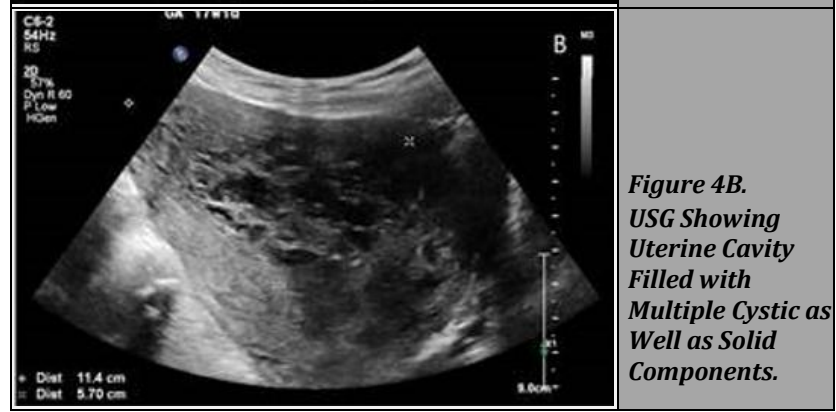

Patient 4

A 30-year-old G3P2L2 female presented with amenorrhoea of 4 months and bleeding per-vaginum for the last 7 days. She gave a history of medical termination of pregnancy (MTP) pill intake one year back followed by D \& E, I / v / o incomplete abortion. Her B-Hcg levels were 2,59,315 mIU / ml. USG and MRI showed numerous cystic lesions occupying the entire uterine cavity with areas of myometrial invasion. A diagnosis of complete molar pregnancy with invasive component was made. She underwent hysterectomy and was discharged in a stable condition.
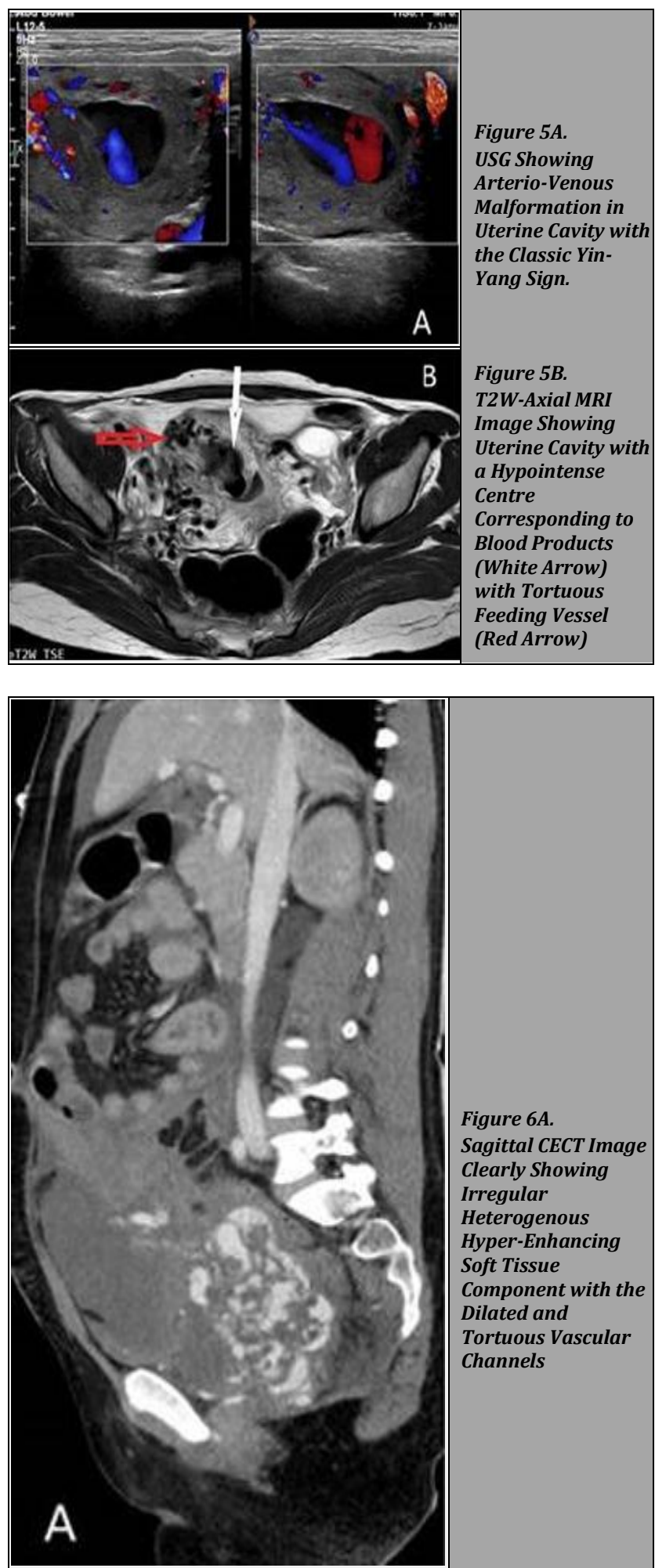


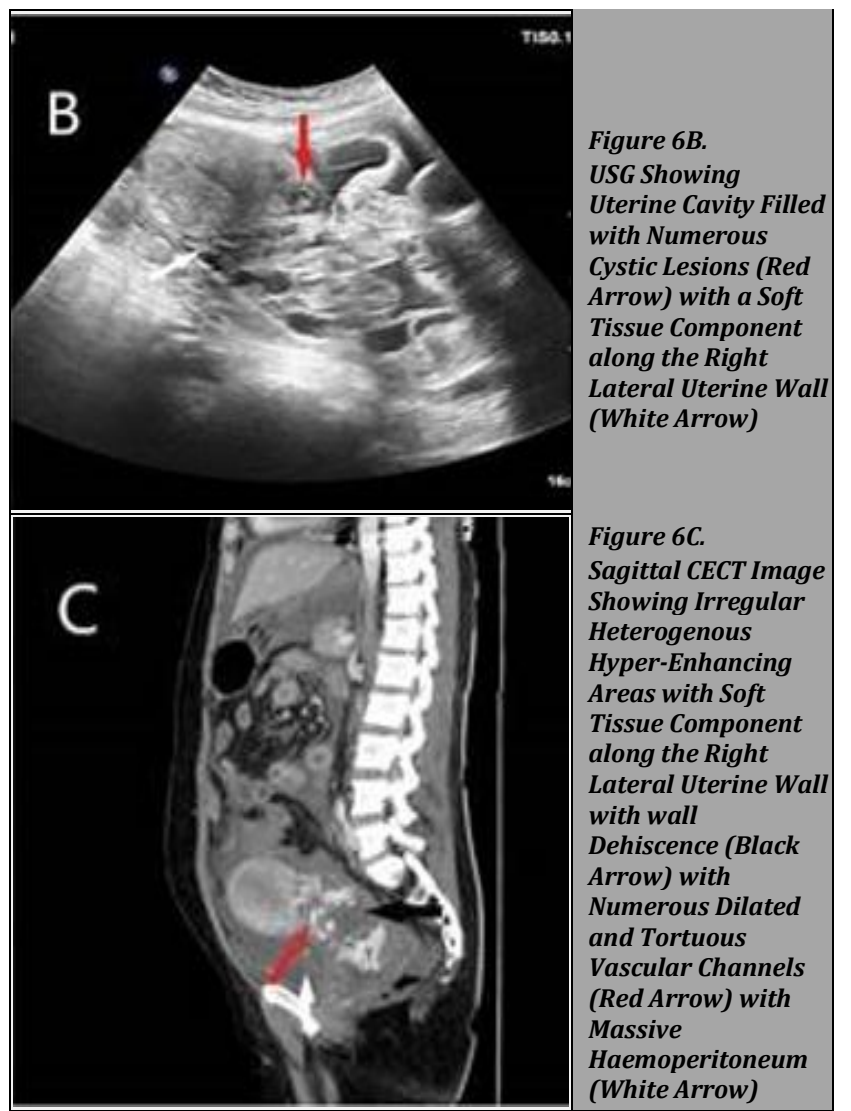

Patient 5

A 40-year-old female presented to the emergency with profuse bleeding per-vaginum for the past 1.5 months. She gave a history of incomplete abortion 8 months back for which she had undergone D \& E. USG showed presence of an irregular ulcerated hyper-vascular lesion along the right lateral uterine wall and an invasive molar component was suspected. 6 months later, patient presented to us with the above said complaints. B-Hcg level was 73,500 mIU / ml. USG and MRI done at our institute showed conversion of the previous ulcerated uterine wall hypervascular mass into arterio-venous malformation. USG guided dilatation and curettage was done which on histopathology confirmed invasive molar component, however, during the procedure there was torrential bleeding for which hysterectomy had to be performed. She was later discharged in a stable condition.

\section{Patient 6}

A 26-year-old female P1L1A1 with previous 1 lower segment Caesarean section (LSCS) presented in a state of shock with progressive abdominal distention and tenderness, amenorrhoea of 7 months and bleeding per-vaginum for last 2 days. 4 months prior to presentation, she underwent D \& E, I / $\mathrm{v} / \mathrm{o}$ incomplete abortion following MTP pill intake. The histopathology report was suggestive of molar pregnancy. She presented to our institute with the above said complaints and a B-HCG level of 4,59,817 mIU / ml. USG and contrast enhanced computed tomography (CECT)-abdomen showed uterine cavity filled with numerous cystic lesions with a soft tissue component along right lateral uterine wall with wall rupture, multiple dilated and tortuous vascular channels, s / o AVM with massive haemoperitoneum. Diagnosis of complete molar pregnancy, myometrial invasion, uterine rupture, bleeding AVM with massive haemoperitoneum was made. She was taken up for emergency laparotomy, but due to excessive blood loss, patient collapsed intra-operatively and could not be revived post- cardiopulmonary resuscitation (CPR).

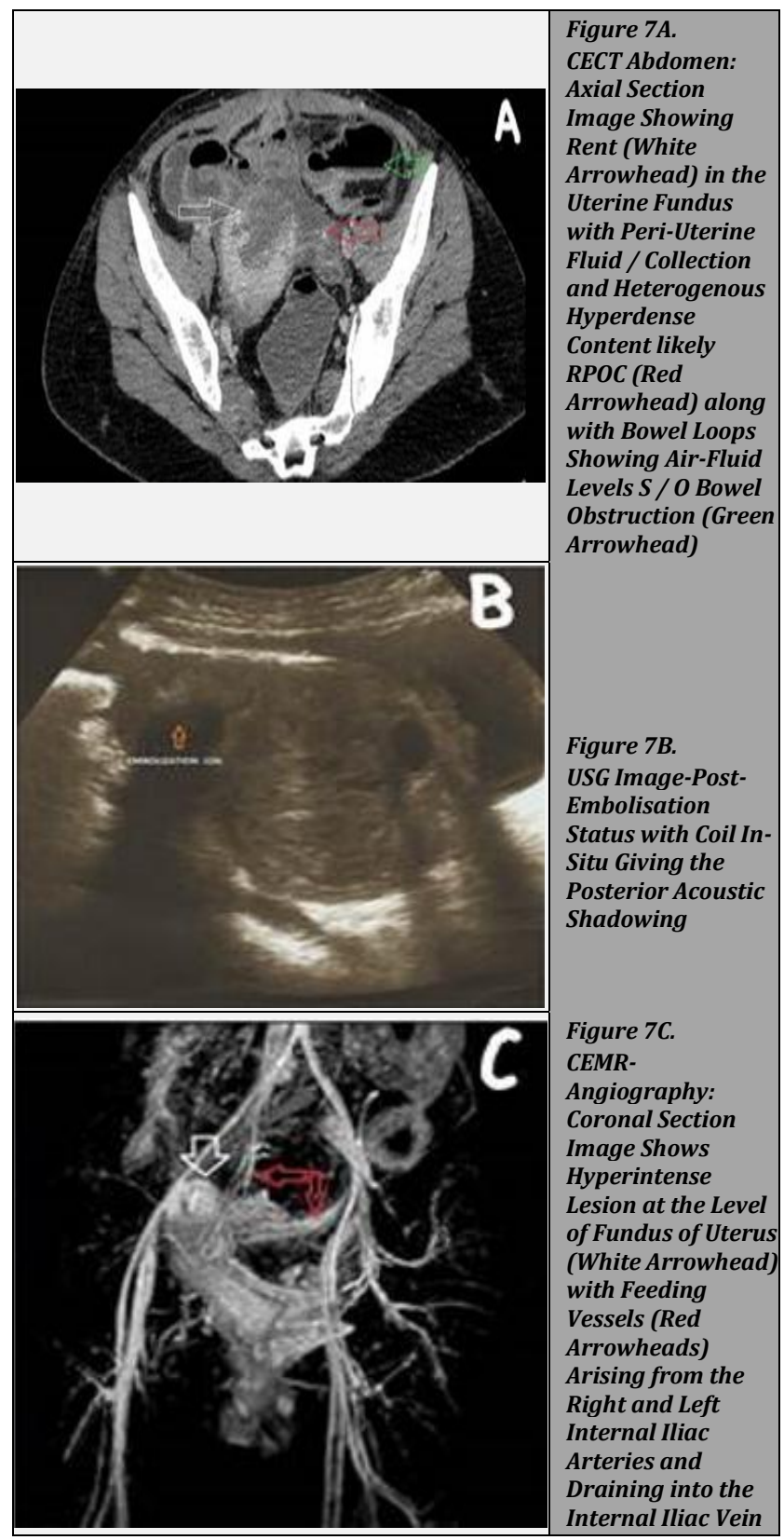

Patient 7

A 35-year-old female P0L0A1 presented to the emergency in a state of shock with progressive abdominal distension and absent bowel sounds. The patient was tachypnoeic having a PR-116 / min, BP-90 / 60 mmHg, RR - 35 bpm, temp. - 100.2 ${ }^{0}$ $\mathrm{f}$ with SP02-78 \% on room air. There was a history of D \& E 1 month prior to presentation. Incomplete abortion at an amenorrhoea of 7 weeks. 21 days following D \& E the patient complained of pain abdomen and vomiting. Her urine pregnancy test (UPT) was positive, and her previous USG was suggestive of right ruptured ectopic pregnancy with hemoperitoneum with ulcerated uterine wall along the fundus.

She underwent exploratory laparotomy followed by right salpingectomy. Her condition worsened and was referred to our institute for further management. USG (using Doppler and spectral analysis) and CECT showed bulky uterus with heterogeneous and highly vascular infiltrating mass in fundus and body of uterus with myometrial invasion; perforation 
along right lateral wall and fundus of uterus; peri-uterine collection; intestinal obstruction and progressively enlarging cystic lesions in the left adnexa with embedded left ovary. Her B-Hcg level was $81000 \mathrm{mIU} / \mathrm{ml}$. She was taken up for exploratory laparotomy followed by uterine repair; products of conception seen coming out via the uterine breech were removed and sent for histopathological analysis which was suggestive of $\mathrm{H}$. mole.
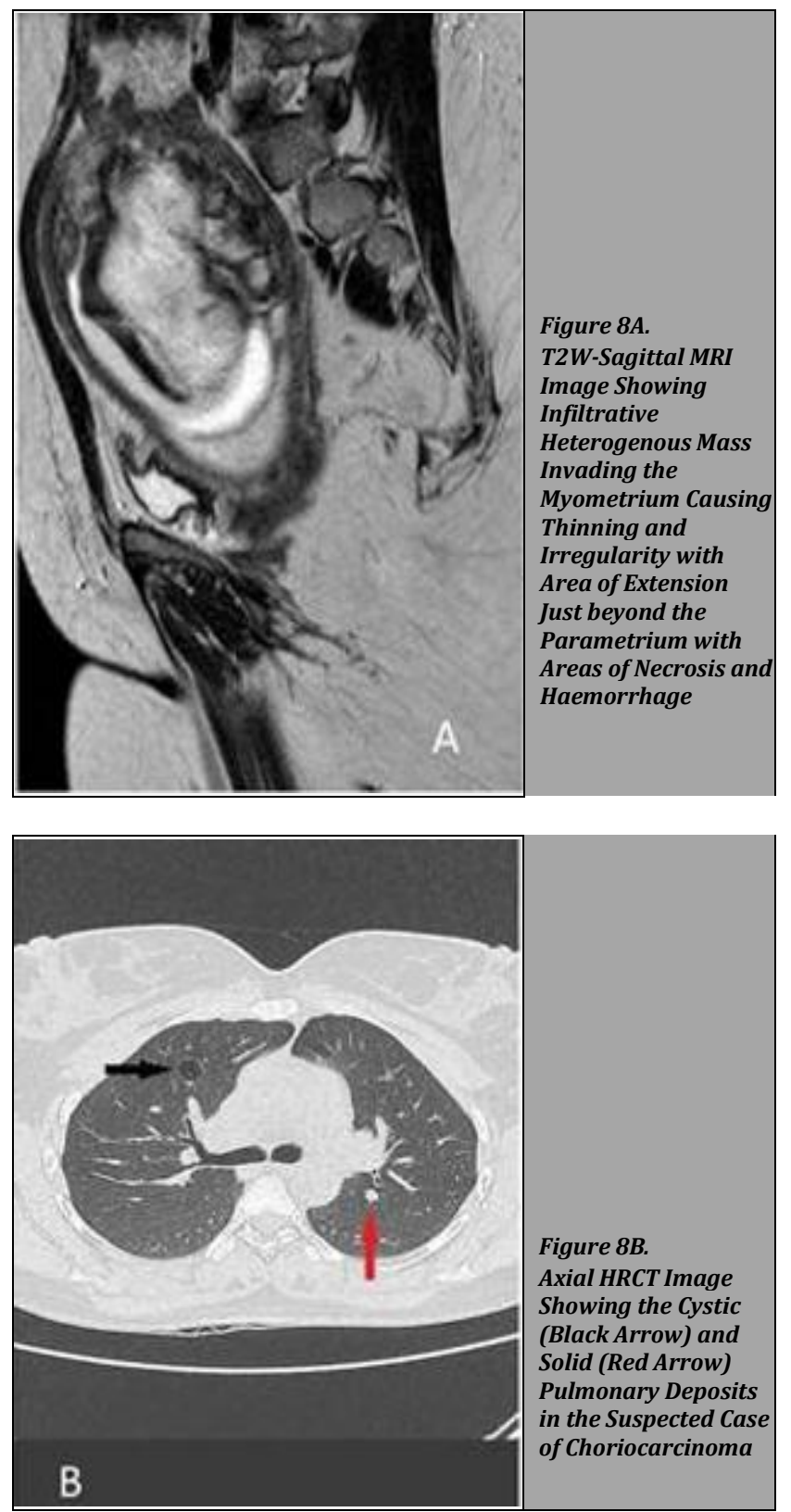

Following this chemotherapy was initiated. During the course of her treatment, the fundal infiltrating mass converted into a bleeding AVM which was confirmed on CEMR pelvis with angiography. Finally, a diagnosis of invasive mole with conversion to AVM was made. She underwent total of 6 cycles of chemotherapy for invasive mole with eventual resolution of the mass and sequential drop in levels of B-Hcg; and uterine artery embolisation for resolution of AVM.

\section{Patient 8}

A 24-year-old female presented with complaints of on-and-off bleeding per-vaginum for the past 3 months. She underwent D
\& E for missed abortion 8 months back. Her B-Hcg level was 91,000 mIU / ml. USG and MRI showed infiltrative heterogenous mass invading the myometrium with area of extension just beyond the parametrium but not into the adnexa. High contrast computed tomography (HRCT)-chest showed metastatic deposits. A provisional diagnosis of choriocarcinoma was made. Patient refused further investigations or management and hence, no definite diagnosis could be made and was lost to follow-up.

\section{RESULTS}

Amongst our study group all the patients included ( $N=8$ ), had a common history of undergoing D \& E in the recent past, either for incomplete abortion or for RPOC.

\section{Diagnosis}

- $12.5 \%(\mathrm{~N}=1)$ of the patients were diagnosed with partial mole.

- $\quad 37.5 \%(\mathrm{~N}=3)$ of the patients presented with complete mole and out of these, $33 \%(\mathrm{~N}=1)$ had simultaneous presence of invasive component.

- $\quad 37.5 \%(\mathrm{~N}=3)$ patients presented with invasive mole and $100 \%$ of these cases complicated into arterio-venous malformation.

- $\quad 12.5 \%(\mathrm{~N}=1)$ of the patients presented with a suspicion of choriocarcinoma.

\section{Management}

- $\quad$ Patients with partial or complete mole underwent D \& E and were discharged satisfactorily.

- Those with invasive mole were given chemotherapy and responded well with no signs of recurrence even on follow-up scans.

- The patient with AVM who underwent timely embolisation, their condition improved with complete resolution of the vascular malformation.

- $\quad 33 \%(\mathrm{~N}=1)$ of the patients with AVM could not be saved because of excessive blood loss due to late presentation.

- $\quad 33 \%(\mathrm{~N}=1)$ of the patients with AVM underwent hysterectomy due to torrential bleeding.

The patient with suspicion of choriocarcinoma did not undergo any confirmatory studies or any treatment and was lost to follow-up.

\section{DISCUSSION}

All the patients included in the study series presented to us with excessive bleeding per vaginal and had a common history of undergoing $\mathrm{D} \& \mathrm{E}$ sometime in the near past. On examination, all of them had $\mathrm{Hb}$ level well below the normal range and a uterine size large for their respective gestational age. 


\begin{tabular}{|c|c|c|c|c|c|c|c|c|c|}
\hline $\begin{array}{l}\text { Case } \\
\text { No. }\end{array}$ & $\begin{array}{l}\text { Age } \\
\text { (Yrs.) }\end{array}$ & Past History & $\begin{array}{c}\text { Clinical } \\
\text { Presentation }\end{array}$ & $\begin{array}{l}\beta \text {-HCG } \\
\text { Levels }\end{array}$ & Radiological Investigations & $\begin{array}{l}\text { Radiological } \\
\text { Diagnosis }\end{array}$ & $\begin{array}{l}\text { Histopathological } \\
\text { Diagnosis }\end{array}$ & Management & Follow-up \\
\hline 1 & 32 & $\begin{array}{c}\text { Incomplete abortion } 8 \\
\text { months back followed } \\
\text { by D \& E }\end{array}$ & $\begin{array}{l}\text { Amenorrhoea } \\
\text { bleeding per } \\
\text { vaginum }\end{array}$ & $\begin{array}{c}3,200 \\
\mathrm{mIU} / \mathrm{ml}\end{array}$ & $\begin{array}{l}\text { USG: Few small cystic lesions } \\
\text { occupying part of the uterine cavity. } \\
\text { No fetal tissue. }\end{array}$ & $\begin{array}{l}\text { Complete molar } \\
\text { pregnancy }\end{array}$ & $\begin{array}{l}\text { Complete molar } \\
\text { pregnancy }\end{array}$ & D \& E & $\begin{array}{c}\text { Serial reduction } \\
\text { in B-HCG levels } \\
\text { on weekly } \\
\text { follow-up. }\end{array}$ \\
\hline 2 & 30 & $\begin{array}{l}\text { Full term IUD delivery } \\
9 \text { months back } \\
\text { D \& E for adherent } \\
\text { RPOC's post delivery }\end{array}$ & $\begin{array}{l}\text { Amenorrhoea } \\
\text { bleeding per vaginal }\end{array}$ & $\begin{array}{l}21,000 \\
\mathrm{mIU} / \mathrm{ml}\end{array}$ & $\begin{array}{l}\text { USG: Numerous cystic lesions } \\
\text { occupying the entire uterine cavity. } \\
\text { MRI-Pelvis: Cystic lesions occupying } \\
\text { the entire uterine cavity with no } \\
\text { myometrial invasion }\end{array}$ & $\begin{array}{c}\text { Complete molar } \\
\text { pregnancy }\end{array}$ & $\begin{array}{l}\text { Complete molar } \\
\text { pregnancy }\end{array}$ & D \& E & $\begin{array}{l}\text { Serial reduction } \\
\text { in B-HCG levels } \\
\text { on weekly } \\
\text { follow-up. }\end{array}$ \\
\hline 3 & 24 & D \& E for RPOC`s & $\begin{array}{l}\text { Amenorrhoea pain } \\
\text { abdomen recurrent } \\
\text { episodes of } \\
\text { vomiting }\end{array}$ & $\begin{array}{l}43,200 \\
\mathrm{mIU} / \mathrm{ml}\end{array}$ & $\begin{array}{c}\text { USG: Uterine cavity filled with } \\
\text { multiple cystic and solid components } \\
\text { with significant internal vascularity } \\
\text { on doppler. Presence of an irregular } \\
\text { gestational sac with fetal tissue } \\
\text { corresponding to gestational age of } 8 \\
\text { weeks } 2 \text { days with absent cardiac } \\
\text { activity }\end{array}$ & $\begin{array}{l}\text { Partial molar } \\
\text { pregnancy }\end{array}$ & $\begin{array}{l}\text { Partial molar } \\
\text { pregnancy }\end{array}$ & D \& E & $\begin{array}{l}\text { Followed up } \\
\text { weekly }\end{array}$ \\
\hline 4 & 30 & D \& E for RPOC's & $\begin{array}{l}\text { Amenorrhoea } \\
\text { bleeding per } \\
\text { vaginum } \\
\text { Expulsion of clots } \\
\text { and few globular } \\
\text { contents }\end{array}$ & $\begin{array}{l}2,59,315 \\
\mathrm{mIU} / \mathrm{ml}\end{array}$ & $\begin{array}{c}\text { USG: } \\
\text { Uterine cavity filled with multiple } \\
\text { cystic and solid components with } \\
\text { significant internal vascularity and } \\
\text { myometrial thinning. } \\
\text { No signs of metastatic deposits. } \\
\text { MRI-Pelvis: } \\
\text { Cystic lesions occupying entire } \\
\text { uterine cavity with areas of } \\
\text { myometrial invasion. } \\
\text { HRCT chest: Normal with no signs of } \\
\text { metastatic deposits. } \\
\text { NCCT-Head: Normal with no signs of } \\
\text { metastatic deposits }\end{array}$ & $\begin{array}{l}\text { Complete molar } \\
\text { pregnancy with } \\
\text { invasive mole }\end{array}$ & $\begin{array}{l}\text { Complete molar } \\
\text { pregnancy with } \\
\text { invasive mole }\end{array}$ & $\begin{array}{c}\text { Total } \\
\text { abdominal } \\
\text { hysterectomy }\end{array}$ & $\begin{array}{c}\text { Discharged in } \\
\text { stable condition }\end{array}$ \\
\hline 5 & 40 & $\begin{array}{l}\text { D \& E for incomplete } \\
\text { abortion } 8 \text { months } \\
\text { back outside USG: } \\
\text { irregular ulcerated } \\
\text { hyper-vascular lesion } \\
\text { along the right lateral } \\
\text { uterine wall: invasive } \\
\text { molar component } \\
\text { suspected }\end{array}$ & $\begin{array}{l}\text { Profuse bleeding } \\
\text { per-vaginum }\end{array}$ & $\begin{array}{c}73,500 \\
\mathrm{mIU} / \mathrm{ml} .\end{array}$ & $\begin{array}{l}\text { USG: Arterio-venous malformation } \\
\text { along uterine wall } \\
\text { CEMRI: Conversion of previous } \\
\text { ulcerated uterine wall mass into } \\
\text { arterio-venous malformation with its } \\
\text { feeding vessels arising from both } \\
\text { internal iliac arteries. }\end{array}$ & $\begin{array}{c}\text { Conversion of } \\
\text { suspected } \\
\text { invasive mole } \\
\text { into AVM }\end{array}$ & $\begin{array}{l}\text { AVM with areas of } \\
\text { trophoblastic } \\
\text { proliferation. }\end{array}$ & $\begin{array}{l}\text { Chemotherapy } \\
\text { with uterine } \\
\text { artery } \\
\text { embolization }\end{array}$ & $\begin{array}{l}\text { Complete } \\
\text { resolution of the } \\
\text { uterine lesion. } \\
\text { No signs of } \\
\text { recurrence }\end{array}$ \\
\hline 7 & 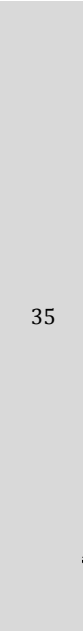 & $\begin{array}{l}1 \text { month prior to } \\
\text { presentation: } \\
\text { Amenorrhoea } \\
\text { Multiple episodes of } \\
\text { bleeding per-vaginal. } \\
\text { D \& E for suspected } \\
\text { incomplete abortion. } \\
1 \text { week prior to } \\
\text { presentation: } \\
\text { Pain abdomen, } \\
\text { vomiting and UPT (+). } \\
\text { USG-Whole abdomen: } \\
\text { right adnexal } \\
\text { ruptured ectopic } \\
\text { pregnancy } \\
\text { haemoperitoneum } \\
\text { ulcerated uterine wall } \\
\text { along the fundus s / o } \\
\text { heterotopic } \\
\text { pregnancy. } \\
\text { Exploratory } \\
\text { laparotomy with right } \\
\text { salpingectomy }\end{array}$ & $\begin{array}{l}\text { Shock } \\
\text { progressive } \\
\text { abdominal } \\
\text { distension } \\
\text { absent bowel } \\
\text { sounds }\end{array}$ & $\begin{array}{c}81,000 \\
\mathrm{mIU} / \mathrm{ml}\end{array}$ & $\begin{array}{l}\text { USG- Whole abdomen: } \\
\text { Highly vascular infiltrating mass in } \\
\text { uterus with myometrial invasion. } \\
\text { Visible rent in uterine fundus and } \\
\text { body with visible spillage of contents. } \\
\text { Peri-uterine collection } \\
\text { intestinal obstruction } \\
\text { mild haemoperitoneum } \\
\text { X-ray chest AP: bronchitis } \\
\text { CECT-whole abdomen: } \\
\text { Irregular heterogenous myometrium } \\
\text { in uterine fundus. } \\
\text { Contained uterine perforation } \\
\text { peri-uterine collection } \\
\text { organised haematoma in left ovary } \\
\text { intestinal obstruction } \\
\text { mild haemoperitoneum }\end{array}$ & $\begin{array}{c}\text { Invasive mole } \\
\text { with conversion } \\
\text { to AVM with } \\
\text { contained uterine } \\
\text { rupture and } \\
\text { haemo- } \\
\text { peritoneum } \\
\\
\end{array}$ & Invasive mole & $\begin{array}{c}\text { Exploratory } \\
\text { laparotomy } \\
\text { Uterine repair } \\
\text { 6xcycles of } \\
\text { chemotherapy } \\
\text { i }\end{array}$ & $\begin{array}{l}\text { During the } \\
\text { course of her } \\
\text { treatment, the } \\
\text { fundal } \\
\text { infiltrating mass } \\
\text { converted into a } \\
\text { bleeding AVM } \\
\text { which was } \\
\text { confirmed on } \\
\text { CEMR pelvis } \\
\text { with } \\
\text { angiography. } \\
\text { Uterine artery } \\
\text { embolisation } \\
\text { was performed } \\
\text { for the same } \\
\text { Eventual } \\
\text { resolution of the } \\
\text { mass and } \\
\text { sequential drop } \\
\text { in levels of B-Hcg }\end{array}$ \\
\hline 8 & 24 & $\begin{array}{l}\text { D \& E for missed } \\
\text { abortion } 8 \text { months } \\
\text { back }\end{array}$ & $\begin{array}{l}\text { On-and-off bleeding } \\
\text { per-vaginum for the } \\
\text { past } 3 \text { months }\end{array}$ & $\begin{array}{l}91,000 \\
\mathrm{mIU} / \mathrm{ml}\end{array}$ & $\begin{array}{l}\text { USG and MRI -infiltrative } \\
\text { heterogenous mass invading the } \\
\text { myometrium with extension just } \\
\text { beyond the parametrium } \\
\text { HRCT-Chest- metastatic deposits }\end{array}$ & $\begin{array}{c}\text { Provisional } \\
\text { diagnosis of } \\
\text { Choriocarcinoma }\end{array}$ & Patient refused & Patient refused & Patient refused \\
\hline
\end{tabular}


Molar pregnancies present commonly in the form of bunch of grapes like vesicles and giving the characteristic snowstorm appearance on USG with or without the presence of any fetal tissue. Most common symptom being irregular vaginal bleeding which is preceded by amenorrhoea.

$20 \%$ of complete moles can become invasive. Invasive moles are characterised microscopically by trophoblastic invasion of the myometrium with identifiable villous structures and rarely metastasize. The clinical presentation may overlap with several other entities such as retained products of conception as well as postpartum endometritis. ${ }^{2}$ Patients have persistent vaginal bleeding with elevated beta human chorionic gonadotropin (HCG) titres post evacuation. The first line of treatment for invasive and persistent moles is chemotherapy which tends to show spontaneous regression post-treatment.

Choriocarcinoma is a highly malignant, necrotic, haemorrhagic, and locally invasive type of GTN with early and extensive vascular invasion resulting in metastases to distant sites even when the primary tumour is small.3,4

Persistent trophoblastic neoplasia is presumed to be invasive mole unless there is presence of metastases which would suggest choriocarcinoma. ${ }^{5}$

Nearly $30 \%$ of patients with GTN have metastases at the time of diagnosis, with the most common locations being to the lungs ( $80 \%$ of cases), vagina (30\%), liver (10\%), and brain (10\%). ${ }^{6}$ Few of the complications of GTD and GTN include uterine AVM and pulmonary AVF.

\section{Acquired Uterine Arterio-Venous Malformations}

Uterine arterio-venous malformation with GTD as well as later, is a very uncommon disorder which can be diagnosed by arteriography, colour Doppler or MRI. The incidence of uterine AVM is difficult to estimate as most of the cases go unnoticed. Fewer than 150 cases have been reported in the literature. ${ }^{7}$

They may occur after a median interval time of 5months to 13 years after the completion of chemotherapy for prior GTN. They often present with profuse, long lasting, unexplained, intermittent episodes of vaginal bleeding occurring with or without pelvic pain or dyspareunia.6,8 Colour Doppler with spectral analysis followed by angiography acts as the tool for definitive diagnosis. ${ }^{6}$

The success of trans-arterial embolisation in treating such lesions and in maintaining fertility has led to its ascendance as the treatment modality of choice; with hysterectomy being reserved as the last resort therapy.6,7

\section{Pulmonary Arterio-Venous Fistula (AVF)}

These can develop within pulmonary metastases of choriocarcinoma after successful completion of chemotherapy. Usually these nodules resolve, however if there is a persistence, this should raise the possibility of a pulmonary AVF. 6

The various types of GTD and GTN as mentioned prior are often indistinguishable on imaging modalities alone. A detailed history, clinical examination, B-HCG values, histopathological correlation as well as post-treatment response helps us to make the final diagnosis.
Seckl MJ et al. in their study found that gestational trophoblastic neoplasms most commonly develop after a previous or a pre-diagnosed GTD, after a previous history of any intervention like D \& E or Caesarean and can also develop after live birth, miscarriage or termination of pregnancy. ${ }^{9}$

\section{Tools for Investigation of Gestational Trophoblastic Neoplasia 1}

- Chest x-ray is enough to diagnose lung metastases and can be used for counting the number of lung metastases to evaluate the risk score. CT-chest may then be used for a more accurate depiction.

- Liver metastases can be diagnosed by ultrasound or CT scanning.

- Brain metastases can be diagnosed by MRI or CT scanning.

Moodley M found that in their audit, $66.7 \%$ of the patients had a previous normal term pregnancy and only $1.8 \%$ of the patients had previous molar pregnancies. ${ }^{10}$

Kitange B et al. in their study found a prevalence of $12.8 \%$ for hydatidiform mole amongst a study group of 180 patients with history of incomplete abortion. ${ }^{11}$

Contractor $\mathrm{S}$ found in his report of a similar presentation of formation of a uterine arterio-venous malformation after performing intervention in the form of $D$ \& $E$ in a case of molar pregnancy. ${ }^{12}$

Ahmed Samy El-Agwany found in his report that in case a patient undergoes any intervention like $\mathrm{D} \& \mathrm{E}$ for an underlying GTD there are high chances to convert into an AVM. 13

\section{CONCLUSIONS}

A history of uterine curettage followed by excessive bleeding in a woman of reproductive age group should raise the suspicion of GTD, wherein the radiologist plays a key role in the initial diagnosis and in guiding the disease management.

Prompt recognition of a molar pregnancy may lead to a less extensive disease process and associated treatment expenditure. Patient compliance likely results in fewer complications and early disease resolution.

Although serum $\beta$-hCG is a highly useful biochemical marker for diagnosing GTD, it is not diagnostic when considered in isolation. Ultrasound is the first line radiological investigation in confirming the diagnosis of GTD in a case suspected on the basis of clinical findings and $\beta$-hCG levels. Ultrasound in combination with Doppler is also a useful tool for diagnosing invasive disease, assessing treatment response, and detecting local recurrence. MRI is invaluable to assess extrauterine disease spread and complications. Chest radiograph, brain MRI, and body $\mathrm{CT}$ are primarily used to rule out any metastatic disease. Conventional angiography can be used to manage patients with heavy bleeding or for chemoembolisation. Prudent use of these imaging techniques permits an early diagnosis and appropriate management, contributing to excellent cure rates of the disease.

The results from our study group, even though small, represent a striking $100 \%$ correlation of the presenting 
spectrum of GTD with a prior history of having undergone D \& $\mathrm{E}$ in the near past for early pregnancy related complications.

Data sharing statement provided by the authors is available with the full text of this article at jemds.com.

Financial or other competing interests: None.

Disclosure forms provided by the authors are available with the full text of this article at jemds.com.

\section{REFERENCES}

[1] Ngan HYS, Seckl MJ, Berkowitz RS, et al. Update on the diagnosis and management of gestational trophoblastic disease. Int J Gynecol Obstet 2018;143(Suppl 2):79-85.

[2] Alessandrino F, Di Silverio E, Moramarco LP. Uterine arteriovenous malformation. J Ultrasound 2013;16(1):41-4.

[3] Wagner BJ, Woodward, Dickey GE. From the archives of the AFIP. Gestational trophoblastic disease: radiologicpathologic correlation. Radiographics 1996;16(1):13148.

[4] Allen SD, Lim AK, Seckl MJ, et al. Radiology of gestational trophoblastic neoplasia. Clin Radiol 2006;61(4):301-13.

[5] Dhanda S, Ramani S, Thakur M. Gestational trophoblastic disease: a multimodality imaging approach with impact on diagnosis and management. Radiol Res Pract 2014;2014:842751.

[6] Shaaban AM, Rezvani M, Haroun RR, et al. Gestational trophoblastic disease: clinical and imaging features. Radiographics 2017;37(2):681-700.
[7] Jain N, Chaudhary J, Yadav S, et al. A rare case of acquired uterine arterio-venous malformation misdiagnosed as molar pregnancy managed successfully with uterine artery embolisation. Gynecol Obstet Case Rep 2019;5(1):71.

[8] Touhami 0, Gregoire J, Noel P, et al. Uterine arteriovenous malformations following gestational trophoblastic neoplasia: a systematic review. Eur J Obstetr Gynecol Reprod Biol 2014;181:54-9.

[9] Seckl MJ, Sebire NJ, Berkowitz RS. Gestational trophoblastic disease. Lancet 2010;376(9742):717-29.

[10] Moodley M, Tunkyi K, Moodley J. Gestational trophoblastic syndrome: an audit of 112 patients. A South African experience. Int J Gynecol Cancer 2003;13(2):2349.

[11] Kitange B, Matovelo D, Konje E, et al. Hydatidiform moles among patients with incomplete abortion in Mwanza City, North Western Tanzania. Afr Health Sci 2015;15(4):10816.

[12] Contractor S, Chung R, Donthireaddy A, et al. Uterine arteriovenous vascular malformation masked by partial molar pregnancy: diagnostic challenge and subsequent embolic treatment. J Obstet Gynaecol India 2014;64(6):442-6.

[13] El-agwany AS. Uterine intramural persistent mole: a case report following molar pregnancy evacuation with arteriovenous malformation. The Egyptian Journal of Radiology and Nuclear Medicine 2014;45(4):1291-4. 